\title{
The influence of desiccation and $U V$ radiation on the development and survival of free-living stages of cyathostomins under field and laboratory conditions
}

\author{
I. LANGROVÁ ${ }^{1, *}$, I. JANKOVSKÁ ${ }^{1}$, J. VADLEJCH ${ }^{1}$, M. LIBRA ${ }^{2}$, A. LYTVYNETS ${ }^{3}$, \\ K. MAKOVCOVÁ ${ }^{1}$
}

\begin{abstract}
${ }^{1}$ Department of Zoology and Fisheries, Faculty of Agrobiology, Food and Natural Resources, Czech University of Agriculture in Prague, Kamýcká 957, 16521 Prague 6-Suchdol, Czech Republic, E-mail: langrova@af.czu.cz; ${ }^{2}$ Department of Physics, Technical Faculty, Czech University of Agriculture in Prague, Kamýcká 872, 16521 Prague 6 - Suchdol, Czech Republic; ${ }^{3}$ Department of Laboratory Animals Breeding and Hygiene, Institute of Physiology, Academy of Sciences of the Czech Republic, Vídeňská 1083, 14220 Prague 4, Czech Republic
\end{abstract}

\begin{abstract}
Summary
The present work describing both laboratory and field experiments was performed to assess the effects of desiccation and UV radiation on the development and survival of free-living stages of equine cyathostomins.

Cyathostomin larvae in horse faeces did not develop to the infective stage when faecal humidity levels dropped below $23 \%$, nonetheless solitary preinfective larvae were still recovered after 151 days (humidity $19.5 \%$ ). The development to infective stage after remoistening occurred for the last time after 54 days following desiccation.

Preinfective stages are susceptible to the effects of the direct desiccation stage. The preinfective larvae were rapidly killed within one minute, the cyathostomin eggs within 5 hours. The numerous normal mobile infective larvae were encountered after 35 days of the desiccated period. The preinfective stage of cyathostomins also showed very little tolerance to direct sun radiation: most eggs were killed by the exposure within 3 hours and the preinfective larvae within 1 hour. The survival of infective larvae was, on the other hand, unaffected by sun radiation after 7 days $(\mathrm{P}<0.05)$. However, desiccated infective larvae were then found to be susceptible to UV radiation, resulting in total mortalities after 5 days.
\end{abstract}

Keywords: cyathostomins; equine strongyles; free-living stages; desiccation; UV radiation

\section{Introduction}

Temperature, humidity and sun light are important factors influencing the development of free-living stages of horses' strongyles. Many field and laboratory experiments have been conducted to determine during which season the nematodes develop. The relations between temperature and the time for the eggs to hatch or to reach the third stage
$\left(\mathrm{L}_{3}\right)$ by equine strongyles were illustrated by a number of authors (Wetzel, 1930, 1931; Baruš, 1963; Rupasinghe \& Ogbourne, 1978; Hasslinger, 1981; Mfitilodze \& Hutchinson, 1987). The estimates of humidity effects on the rate of development are less thorough (English, 1979a, b; Ogbourne, 1972; Mfitilodze \& Hutchinson, 1987, 1988). Nevertheless, humidity is important for the development of strongyle parasites of horses, the minimum humidity content of faecal pellets as well as temperature being the key factors. Mfitilodze and Hutchinson (1987) found out that humidity affected larval development of equine strongyles especially at higher temperatures of $25-39^{\circ} \mathrm{C}$. But in the case of faecal pellets, there is difficulty in assessing the actual conditions which the nematodes are exposed to within the pellets; and in the case of field experiments there are also adjacent factors affecting the survival, such as temperature and the effects of predation and parasitism. Cyathostomins, (Nematoda: Strongyloidea: Cyathostominea), often referred to as small strongyles, are recognized as important parasites of horses. They consist of 51 species although only 5 to 10 of these commonly occur in large numbers in natural conditions (Lichtenfels et al., 1998; Lichtenfels et al., 2002). Monoinfection is probably impossible (Klei \& Chapman, 1999). Baruš (1962) found 27 small strongyle species (prevalences of individual species $1.2-78 \%$ ) in the Czech Republic.

Equine strongyles still represent a threat to the health of horses. They can cause various complications and it may not be apparent that horses are infected. Parasites can lower horse's resistance, deplete valuable nutrients, cause gastrointestinal upset and may lead to colic, intestinal ruptures and etc. The free-living stages of these parasites are often overlooked and not considered by producers, whereas the knowledge of their biology may be utilized by ecology control of these parasites. Some reports have been 
published recently, however, only studying the free-living stages of trichostrongyles of ruminants (Stromberg, 1997; Fernández et al., 2001; Larsson et al., 2006).

The aim of this project is to extend the previous studies and findings of many authors (Baruš, 1963; Rupasinghe \& Ogbourne, 1978; Hasslinger, 1981; Mfitilodze \& Hutchinson, 1987), to improve the general knowledge concerning these significant strongyles and helping to control them.

The objectives of the study were to ascertain the following: (i) the development and survival of free-living stages of equine cyathostomins in $5 \mathrm{~g}$ of faeces; (ii) the survival of free-living stages of cyathostomins in desiccated state; (iii) the effect of UV radiation on the development and survival of free-living stages of cyathostomins.

\section{Material and methods}

Horses with mixed natural cyathostomin (Cyathostominea) infection were used as donors for faecal material, faeces dropped were immediately collected in bags.

The development and survival of free-living stages of cyathostomes in $5 \mathrm{~g}$ offaeces

The fresh faeces were homogenized to ensure uniform distribution of eggs and then divided into 30 samples weighing $5 \mathrm{~g}$ (representing 366 eggs per gram).

The faeces were examined using the modified Breza flotation and McMaster method (Wetzel, 1951). The samples were placed in uncovered dishes and incubated at $23.8{ }^{\circ} \mathrm{C}$ with a relative humidity of $53.5 \%$ (incubator ES 500-Trigon). Faecal samples were examined on days 1, 7, 10, 17, 24, 54, 151, 179 and 184 post-incubation. Three samples were removed from incubators on each occasion. The first sample, for the recovery and the counting of developmental stages, the second sample, for the determination of humidity of faeces and the third sample for remoistening of the faecal sample.

The remoistened faeces were kept in relative humidity at a minimum of $70 \%$ and incubated in closed dishes for 3 days. The developmental stages were recovered using Baermann method (Eckert, 1960), the humidity of faeces was measured according to standard method (drying in the dryer at $105^{\circ} \mathrm{C}$, Ц̆SN 467092-3).

The larvae were assigned to the following groups (Rommel et al., 2000 and personal observation): preinfective first stage larvae $\left(\mathrm{L}_{1}\right)$ freshly hatched $(\mathrm{A})$ and older first stage larvae (B), preinfective second stage larvae $\left(\mathrm{L}_{2}, \mathrm{C}\right)$, second stage larvae immediately before metamorphosis to infective stage (D) and infective stage $\left(\mathrm{L}_{3}, \mathrm{E}\right)$.

Survival of free-living stages of cyathostomins in direct and continuous desiccated state

The average egg count of a fresh faecal sample was determined by using the Mc Master method. One part of infected faeces was processed for the recovery of clean suspensions of embryonated cyathostomins eggs by using the technique of Bello and Gordon (1970). The second part was incubated at $23{ }^{\circ} \mathrm{C}$ in thermostat. After 1,3 and 10 days, the preinfective and the infective larvae were collected by means of a Baermann funnel. The first stage larvae were obtained after an incubation period of 1 day; the second stage larvae after 3 days, and the third stage larvae after 10 days of incubation.

A minimum of 100 individuals (eggs, first, second and third stage larvae) were put into $0.5 \mathrm{ml}$ of water in watch glasses (40-mm in diameter) and transferred to the chamber of known RH (relative humidity) - $56 \%$ and temperature of $23{ }^{\circ} \mathrm{C}$. The six watch glasses with nematodes were prepared for each stage, 3 for desiccation (treatment group) and 3 for the control group. The free-living stages were incubated in uncovered watch glasses (treatment group) or closed watch glasses (control group). The water was evaporated within 3 hours and the time began to be counted after this period. The free-living stages were desiccated for 1, 3, 10, 28 and 35 days. After this defined period, water was added and after a period of 24 hours vitality, failure and mobility were recorded. Revived larvae were active, while non-revived ones were limp, granular, and motionless. The qualities of control samples (kept in water) were recorded in the same intervals (Table 2).

\section{Survival of infective larvae of cyathostomins in disconti- nuous desiccated state}

The infective larvae were kept in desiccated conditions for $1,3,7,14,15$ and 20 days. After this period, larvae were remoistened for 1 or 7 days and were again brought to dry conditions. These alternations were repeated several times (see Table 3). After a defined period, water was added and after a period of 24 hours vitality, mobility and failure were evaluated. Mobility and failure were always checked in both tested and control samples.

\section{The effect of $U V$ radiation on the free-living stages of cyathostomins}

The studies were planned to be conducted in natural as well as artificial conditions with two different approaches: (1) natural UV radiation: the experimental plots and (2) laboratory UV radiation experiments, performed by means of mercury lamp (Mercury discharge lamp, UV dose $2 \mathrm{~W} / \mathrm{m}^{2}$ ).

The infected faeces were obtained by the same method as with previous observation. The $5 \mathrm{~g}$ of faeces were exposed to the effects of natural (the sun) and an artificial source. The experimental plots (haplic Chernozem, texture clayloam) were located on a pasture at the Czech University of Agriculture in Prague. Horses never grazed on the plot. The pasture consists mainly of bluegrass (Poa pratensis) but other species of grasses and forbs are also present (Poa trivialis, Elytrigia repens, Dactylis glomerata, Deschampsia cespitosa).

During the laboratory experiments, we simulated the solar radiation in the UV region of the spectrum by the special 
high pressure mercury discharge tube for artificial sunlight generated using special HERAEUS M282 clear quartz glass. The absorption edge of this special quartz glass is shifted to longer wave lengths and it is comparable with the absorption edge of the ozone layer. The hard UV radiation of the discharge is filtered. The discharge lamps were connected with standardized ballast. The artificial UV spectrum and solar spectrum falling on the earth surface in the UV region is comparable. Each light source was left switched on for 15 minutes, for thermal stabilization, before the measurement.

The faeces were used fresh (containing eggs) or after 1, 3 and 7 days cultivation in laboratory conditions (faeces then contained $\mathrm{L}_{1}, \mathrm{~L}_{2}$ and $\mathrm{L}_{3}$ larvae, respectively).

In the first case, $5 \mathrm{~g}$ samples of faeces containing freeliving stages of cyathostomins in various stages of development, were exposed to summer sun (July) every day between 8 a.m. and 4 p.m. Only sunny sequential days were used for this experiment, with mean daily air temperature above $26^{\circ} \mathrm{C}$. The day of deposition of the faeces is designated as day 0 in the Tables (Tables 4 and 5).

In both, natural and artificial experiments, the free-living stages in faeces were checked for the ability of larval development - i.e. whether the larvae came through a Baerman funnel after 24 hours, at daily (the first week) and then at weekly intervals. In each of these cases, larval stage, mobility and damage of larvae were ascertained.

The same procedure was used for free-living stages in tap water $(5 \mathrm{ml}$ of water, minimally 100 individuals per one watch glass) and for desiccated larvae as well. Obtaining and conditioning of free-living stages of cyathostomins was the same as in previous laboratory observation. The watch glass slides with eggs, $\mathrm{L}_{1}, \mathrm{~L}_{2}$ and $\mathrm{L}_{3}$ larvae (in viable as well as in desiccated state) were exposed to the effects of natural (the sun) and artificial source (see above). Control samples were conditioned to standard laboratory conditions (relative humidity of $56 \%$ and temperature $23^{\circ} \mathrm{C}$ ).

Statistical analyses were carried out using SAS (ANOVA, SAS Institute, 2004). The level of significance was set at $\mathrm{P}<0.05$.

\section{Results}

The development and survival of free-living stages of cyathostomins in $5 \mathrm{~g}$ of faeces

The humidity content and larval yields from $5 \mathrm{~g}$ faeces samples incubated in uncovered dishes are given in Table 1. Cyathostomin larvae in horse faeces did not develop to the infective stage when faecal humidity levels dropped below $23 \%$, the solitary preinfective larvae were still recovered after 151 days (humidity of $19.5 \%$ ). The development to the infective stage after remoistening occurred for the last time after 54 days.
Table 1. Effect of natural desiccation and subsequent rehydratation on the development and survival of cyathostomes in $5 \mathrm{~g}$ of faeces

\begin{tabular}{|c|c|c|c|}
\hline $\begin{array}{c}\text { Time period of } \\
\text { desiccation } \\
\text { (days) }\end{array}$ & $\begin{array}{l}\text { Larvae }^{a} \\
\quad(\%)\end{array}$ & $\begin{array}{l}\mathrm{RH}^{\mathrm{c}} \\
(\%)\end{array}$ & $\begin{array}{c}\text { Remoistened } \\
\text { larvae }{ }^{\mathrm{d}} \\
(\%) \\
\end{array}$ \\
\hline \multirow{2}{*}{ 2. } & \multirow{2}{*}{$100(\mathrm{~A})^{\mathrm{b}}$} & \multirow{2}{*}{34.7} & $83.6(\mathrm{C})$ \\
\hline & & & 16.4(D) \\
\hline 5 & $100(\mathrm{~A})$ & 29.1 & $100(\mathrm{E})$ \\
\hline \multirow[t]{3}{*}{7} & $30(\mathrm{~A})$ & \multirow[t]{3}{*}{22.8} & 2.4 (D) \\
\hline & $60(\mathrm{~A} / \mathrm{B})$ & & $97.6(\mathrm{E})$ \\
\hline & $10(\mathrm{~B})$ & & \\
\hline 10 & $100(\mathrm{~A})$ & 23.6 & $100(\mathrm{E})$ \\
\hline \multirow[t]{5}{*}{17} & $72.5(\mathrm{~A})$ & \multirow[t]{5}{*}{23.8} & $1.4(\mathrm{~A})$ \\
\hline & 17.5.(B) & & 80.4 (B) \\
\hline & $2.5(\mathrm{C})$ & & 12.8 (D) \\
\hline & 5 (D) & & $5.4(\mathrm{E})$ \\
\hline & $2.5(\mathrm{E})$ & & \\
\hline \multirow[t]{4}{*}{24} & $91.4(\mathrm{~A})$ & \multirow[t]{4}{*}{21.0} & $2.8(\mathrm{~A})$ \\
\hline & $8.6(\mathrm{~B})$ & & $19.4(\mathrm{C})$ \\
\hline & & & 19.4 (D) \\
\hline & & & $58.4(\mathrm{E})$ \\
\hline \multirow[t]{5}{*}{54} & $67.6(\mathrm{~A})$ & \multirow[t]{5}{*}{21.8} & 17.6 (A) \\
\hline & $32.4(\mathrm{~B})$ & & $11.8(\mathrm{~B})$ \\
\hline & & & $5.9(\mathrm{C})$ \\
\hline & & & 29.4 (D) \\
\hline & & & $35.3(\mathrm{E})$ \\
\hline 151 & $100(\mathrm{~B})$ & 19.5 & 0 \\
\hline 179 & 0 & 18.1 & 0 \\
\hline 184 & 0 & 17.8 & 0 \\
\hline
\end{tabular}

a - the larvae obtained from $5 \mathrm{~g}$ faeces after defined period of desiccation; ${ }^{\mathrm{b}} \mathrm{A}, \mathrm{B}, \mathrm{C}, \mathrm{D}, \mathrm{E}$ - the first stage larvae freshly hatched (A), the older first stage larvae (B), the second stage larvae (C), the second stage immediately before metamorphosis to infective stage (D), the infective stage (E); ${ }^{\circ} \mathrm{RH}$ - relative humidity; A,B,C,D,E - the first stage larvae freshly hatched (A), the older first stage larvae (B), the second stage larvae $(C)$, the second stage immediately before metamorphosis to infective stage (D), the infective stage (E); ${ }^{\mathrm{d}}$ - the larvae obtained from $5 \mathrm{~g}$ faeces after defined period of desiccation and subsequently 3 days of dehydration

The survival of free-living stages of cyathostomins in desiccated state

Eggs and preinfective larvae are very susceptible to dry conditions, which results in total mortalities among all preinfective stages. Cyathostomins preinfective larvae were rapidly killed within one minute, cyathostomin eggs then within 5 hours.

The results of the direct desiccation on free-living stages of cyathostomins are summarized in Table 2. In water-sprinkled samples of infective larvae, numerous normal mobile larvae were encountered after 35 days of desiccated period; the difference to the control was not significant $(\mathrm{P}<0.05)$. The 3 days desiccated period had, however, a significant impact on the survival rate of the infective larvae. 
Table 2. Effect of direct and continuous desiccation on eggs, preinfective $\left(\mathrm{L}_{1}\right.$ and $\left.\mathrm{L}_{2}\right)$ and infective $\left(\mathrm{L}_{3}\right)$ larvae of cyathostomes

\begin{tabular}{ccccccccc}
\hline Days & & $\begin{array}{c}\text { Eggs } \\
\text { (able to develop) }\end{array}$ & \multicolumn{2}{c}{$\begin{array}{c}\mathrm{L}_{1} \\
\text { (mobile/damaged) }\end{array}$} & $\begin{array}{c}\mathrm{L}_{2} \\
\text { (mobile/damaged) }\end{array}$ & \multicolumn{2}{c}{$\begin{array}{c}\mathrm{L}_{3} \\
\text { (mobile/damaged) }\end{array}$} \\
\hline & $\mathrm{t}^{\mathrm{a}}$ & $\mathrm{c}^{\mathrm{b}}$ & $\mathrm{t}$ & $\mathrm{c}$ & $\mathrm{t}$ & $\mathrm{c}$ & $\mathrm{c}$ & $\mathrm{c}$ \\
0 & 0 & $84.4 \pm 4.2^{\mathrm{c}}$ & 0 & $100^{\mathrm{d}} / 0^{\mathrm{e}} \pm 0 / 0$ & 0 & $99.3 / 0 \pm 0.9 / 0$ & $100 / 0 \pm 0 / 0$ & $100 / 0 \pm 0 / 0$ \\
1 & - & - & - & - & - & - & $92.3 / 5.2 \pm 5.7 / 1.7$ & $100 / 0 \pm 0 / 0$ \\
3 & - & - & - & - & - & - & $29.7 / 1.7 \pm 12.0 * / 0.9$ & $96.6 / 0 \pm 2.1 / 0$ \\
10 & - & - & - & - & - & - & $59.7 / 38.9 \pm 16.1 / 10.4$ & $79 / 8.4 \pm 8.1 / 1.1$ \\
28 & - & - & - & - & - & - & $11.7 / 7.3 \pm 14.4 * / 4.1$ & $73.6 / 8.7 \pm 10.1 / 2.0$ \\
35 & - & - & - & - & - & - & $10.3 / 3.3 \pm 14.6 / 0.7$ & $61 / 23.8 \pm 15.5 / 6.6$ \\
\hline
\end{tabular}

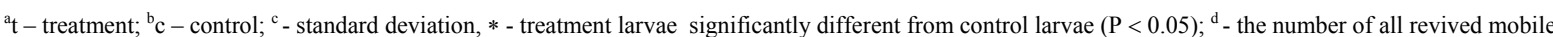
larvae; ${ }^{\mathrm{e}}$ - the number of revived mobile larvae with visible damage

Table 3. Effect of discontinuous desiccation of infective cyathostome larvae

\begin{tabular}{|c|c|c|c|c|c|}
\hline \multirow{3}{*}{$\begin{array}{l}\text { Time period of } \\
\text { desiccation and } \\
\text { following } \\
\text { rehydratation } \\
\text { (days) }\end{array}$} & \multirow{3}{*}{$\begin{array}{c}\text { Number } \\
\text { of days in } \\
\text { total }\end{array}$} & \multicolumn{4}{|c|}{$\begin{array}{l}\text { Number of larvae - final stage } \\
\text { (mobile/damaged) }\end{array}$} \\
\hline & & \multicolumn{2}{|c|}{ Treatment groups } & \multicolumn{2}{|c|}{ Control groups } \\
\hline & & Mean & SD f & Mean & SD \\
\hline $1^{\mathrm{a}} / 1^{\mathrm{b}}$ & $40^{\mathrm{c}}$ & $23.3^{\mathrm{d}} / 21.3^{\mathrm{e}}$ & $25.6 / 23.2$ & $55.4 / 31.9$ & $27.5 / 19.4$ \\
\hline $3 / 1$ & 40 & $4.0 / 1.3$ & $5.7 / 0.7$ & $58.2 / 25.5$ & $32.8 / 20.4$ \\
\hline $7 / 1$ & 40 & $26.0 / 21.7$ & $12.4 / 10.3$ & $87.4 / 23.5$ & $18.4 / 12.2$ \\
\hline $14 / 7$ & 63 & $0.7 / 0.3$ & $0.9 / 0.1$ & $36.7 / 28.4$ & $41.1 / 29.9$ \\
\hline $15 / 7$ & 66 & $26.0 / 24.5$ & $9.9 / 1.5$ & $69.8 / 46.9$ & $55.5 / 41.3$ \\
\hline $20 / 7$ & 108 & $13.7 / 8.7$ & $13.5 / 7.1$ & $32.3 / 24.9$ & $35.8 / 26.6$ \\
\hline
\end{tabular}

a - the number of days when the infective larvae were kept in desiccated state; ${ }^{b}$ - the number of days when the infective larvae were remoistened; ${ }^{c}$ - the total number of days when the infective larvae were kept in turns in desiccated and remoistened states; ${ }^{\mathrm{d}}-$ the number of all revived mobile larvae; ${ }^{\text {e }}-$ the number of revived mobile larvae with visible damage; ${ }^{\mathrm{f}}$ - standard deviation, $*$ treatment larvae significantly different from control larvae $(\mathrm{P}<0.05)$

Table 4. Effect of solar radiation on free-living stages of cyathostomes $\left(\mathrm{L}_{1}-\right.$ the first stage larvae, $\mathrm{L}_{2}-$ the second stage larvae, $\mathrm{L}_{3}-$ the third stage larvae) contained in $5 \mathrm{~g}$ faeces

\begin{tabular}{|c|c|c|c|c|c|c|c|c|c|}
\hline \multirow{2}{*}{\multicolumn{2}{|c|}{$\begin{array}{c}\begin{array}{c}\text { Free-living stage in } \\
\text { faeces (on day 0) }\end{array} \\
\begin{array}{c}\text { Time period of } \\
\text { exposition (days) }\end{array}\end{array}$}} & \multicolumn{2}{|c|}{ Eggs } & \multicolumn{2}{|c|}{$\mathrm{L}_{1}$} & \multicolumn{2}{|c|}{$\mathrm{L}_{2}$} & \multicolumn{2}{|c|}{$\mathrm{L}_{3}$} \\
\hline & & $\mathrm{t}^{\mathrm{a}}$ & $\mathrm{c}^{\mathrm{b}}$ & $\mathrm{t}$ & $\mathrm{c}$ & $\mathrm{t}$ & $\mathrm{c}$ & $\mathrm{t}$ & $\mathrm{c}$ \\
\hline \multirow[t]{3}{*}{1} & $\mathrm{~L}_{1}$ & $53.3 \pm 13.5^{\mathrm{c}}$ & $71.4 \pm 9.5$ & $38 \pm 12.1$ & $12.3 \pm 1.1$ & 0 & 0 & 0 & 0 \\
\hline & $\mathrm{L}_{2}$ & 0 & 0 & $25.7 \pm 14.4$ & $79.6 \pm 11.2$ & $40.3 \pm 26.2$ & $21.2 \pm 4.5$ & 0 & 0 \\
\hline & $\mathrm{L}_{3}$ & 0 & 0 & 0 & 0 & $0.3 \pm 0.5^{*}$ & $7.3 \pm 2.1$ & $58.3 \pm 11.7$ & $78.4 \pm 6.7$ \\
\hline \multirow[t]{3}{*}{7} & $\mathrm{~L}_{1}$ & $4 \pm 3.7^{*}$ & $88.8 \pm 5.2$ & 0 & 0 & 0 & 0 & 0 & 0 \\
\hline & $\mathrm{L}_{2}$ & 0 & 0 & $0.7 \pm 0.9^{*}$ & $29.5 \pm 7.1$ & $4 \pm 2.9$ & 0 & 0 & 0 \\
\hline & $\mathrm{L}_{3}$ & 0 & 0 & $0.3 \pm 0.47$ & 0 & $0.7 \pm 0.94$ & $16.4 \pm 8.8$ & $55.7 \pm 21.1$ & $132.6 \pm 31.2$ \\
\hline \multirow[t]{3}{*}{14} & $\mathrm{~L}_{1}$ & $0^{*}$ & $78.4 \pm 9.1$ & 0 & 0 & 0 & 0 & 0 & 0 \\
\hline & $\mathrm{L}_{2}$ & $0.3 \pm 0.5$ & $1.3 \pm 1.3$ & $0 *$ & $19.4 \pm 3.2$ & 0 & 0 & 0 & 0 \\
\hline & $\mathrm{L}_{3}$ & 0 & $1 \pm 0.8$ & 0 & 0 & $3.7 \pm 2.6$ & $19.6 \pm 5.5$ & $17 \pm 4.6^{*}$ & $54.4 \pm 11.1$ \\
\hline \multirow[t]{3}{*}{21} & $\mathrm{~L}_{1}$ & $0^{*}$ & $41.5 \pm 7.6$ & 0 & 0 & 0 & 0 & 0 & 0 \\
\hline & $\mathrm{L}_{2}$ & $0.3 \pm 0.5^{*}$ & $12.4 \pm 4.1$ & $0^{*}$ & $54.5 \pm 7.5$ & 0 & 0 & 0 & 0 \\
\hline & $\mathrm{L}_{3}$ & 0 & 0 & 0 & $1 \pm 0.57$ & $1.3 \pm 1.9^{*}$ & $37.3 \pm 9.9$ & $18.3 \pm 10.9$ & $52.5 \pm 12.7$ \\
\hline \multirow[t]{3}{*}{28} & $\mathrm{~L}_{1}$ & $0^{*}$ & $46.4 \pm 11.2$ & 0 & 0 & 0 & 0 & 0 & 0 \\
\hline & $\mathrm{L}_{2}$ & $0 *$ & $4.1 \pm 0.5$ & $0 *$ & $15.4 \pm 9.2$ & 0 & 0 & 0 & 0 \\
\hline & $\mathrm{L}_{3}$ & 0 & 0 & $0^{*}$ & $3.1 \pm 1.1$ & $0^{*}$ & $12.4 \pm 2.2$ & $15 \pm 9.9^{*}$ & $79.5 \pm 15.5$ \\
\hline
\end{tabular}

${ }^{\mathrm{a}} \mathrm{t}$ - treatment; ${ }^{\mathrm{b}} \mathrm{c}$ - control; ${ }^{\mathrm{c}}$ - standard deviation, $*$ - treatment larvae significantly different from control larvae $(\mathrm{P}<0.05)$ 
Survival of infective larvae of cyathostomins in discontinuous desiccated state

The infective larvae survived well in discontinuous desiccated state (Table 3). The rate of larval survival varied, depending on the different number of days in dry condition. In the case of alternate desiccation type 1:1 for 40 days (one day desiccation, following one day rehydration), $2-56 \%$ of larvae stopped their movement and died. The type of desiccation 3/1 showed reduced larval motility after 4 days exposure to this desiccated state. However, at the end of each observation, no significant differences $(\mathrm{P}<$ $0.05)$ were observed between treatment and control groups.
The effect of $U V$ radiation on free-living stages of cyathostomins

Sunshine was effective in the destruction of eggs and preinfective larvae in $5 \mathrm{~g}$ faeces (Table 4). No infective larvae of cyathostomins were obtained from faeces containing eggs during all tested period, from faeces contained $\mathrm{L}_{1}$ (on day 0 ) were infective larvae recovered only after 1 week sun exposition. The recoveries of $\mathrm{L}_{3}$ larvae from faeces originally contained $\mathrm{L}_{2}$ and $\mathrm{L}_{3}$ larvae significantly decreased on day 21 and on day 14, respectively.

The effect of sunshine on egg and larval survival in water was demonstrated in Table 6 and 8 . The preinfective stage

Table 5. Effect of artificial UV radiation on free-living stages of cyathostomes $\left(\mathrm{L}_{1}-\right.$ the first stage larvae, $\mathrm{L}_{2}-$ the second stage larvae, $\mathrm{L}_{3}-$ the third stage larvae) contained in $5 \mathrm{~g}$ faeces

\begin{tabular}{|c|c|c|c|c|c|c|c|c|c|}
\hline \multicolumn{2}{|c|}{$\begin{array}{l}\text { Free-living stage } \\
\text { in faeces (on day 0) }\end{array}$} & \multicolumn{2}{|c|}{ Eggs } & \multicolumn{2}{|c|}{$\mathrm{L}_{1}$} & \multicolumn{2}{|c|}{$\mathrm{L}_{2}$} & \multicolumn{2}{|c|}{$\mathrm{L}_{3}$} \\
\hline \multicolumn{2}{|c|}{$\begin{array}{l}\text { Time period of } \\
\text { exposition (days) }\end{array}$} & $t^{a}$ & $c^{b}$ & $\mathrm{t}$ & $\mathrm{c}$ & $\mathrm{t}$ & $\mathrm{c}$ & $\mathrm{t}$ & $\mathrm{c}$ \\
\hline \multirow[t]{3}{*}{1} & $\mathrm{~L}_{1}$ & $114.7 \pm 15.2^{\mathrm{c}}$ & $142.2 \pm 24.5$ & $61 \pm 52.7$ & $21.1 \pm 25.5$ & 0 & 0 & 0 & 0 \\
\hline & $\mathrm{L}_{2}$ & 0 & 0 & $38.3 \pm 26.6$ & $56.5 \pm 11.6$ & $64.7 \pm 23.2$ & $132.4 \pm 25.5$ & 0 & 0 \\
\hline & $\mathrm{L}_{3}$ & 0 & 0 & 0 & 0 & $2.5 \pm 2.2^{*}$ & $25.6 \pm 5.5$ & $103.3 \pm 26.1$ & $154.1 \pm 22.5$ \\
\hline \multirow[t]{3}{*}{7} & $\mathrm{~L}_{1}$ & $33.3 \pm 19.7^{*}$ & $172.2 \pm 38.8$ & 0 & 0 & 0 & 0 & 0 & 0 \\
\hline & $\mathrm{L}_{2}$ & $7.7 \pm 10.8$ & $6.3 \pm 7.5$ & $32.3 \pm 6.6$ & $58.4 \pm 12.2$ & $1.7 \pm 2.4$ & $3.1 \pm 1.1$ & 0 & 0 \\
\hline & $\mathrm{L}_{3}$ & 0 & 0 & $1.7 \pm 1.7$ & $4.7 \pm 11.6$ & $22 \pm 9.2$ & $54.7 \pm 5.8$ & $88.3 \pm 31.7$ & $87.4 \pm 11.1$ \\
\hline \multirow[t]{3}{*}{14} & $\mathrm{~L}_{1}$ & $45 \pm 23.4$ & $82.2 \pm 16.6$ & 0 & 0 & 0 & 0 & 0 & 0 \\
\hline & $\mathrm{L}_{2}$ & $4.7 \pm 6.6$ & $43.2 \pm 15.1$ & $31.7 \pm 13.0$ & $82.4 \pm 28.9$ & $2 \pm 2.8$ & $5.1 \pm 2.2$ & 0 & 0 \\
\hline & $\mathrm{L}_{3}$ & 0 & 0 & $1.7 \pm 2.36$ & 0 & $38.3 \pm 17.6$ & $68.4 \pm 11.6$ & $30 \pm 10.6$ & $52.4 \pm 9.9$ \\
\hline \multirow[t]{3}{*}{21} & $\mathrm{~L}_{1}$ & $18.3 \pm 9.3 *$ & $88.8 \pm 24.5$ & $1 \pm 1.41$ & 0 & 0 & 0 & 0 & 0 \\
\hline & $\mathrm{L}_{2}$ & $0.3 \pm 0.47$ & $12.1 \pm 11.9$ & $13.3 \pm 7.4^{*}$ & $75.4 \pm 15.5$ & $7.7 \pm 10.84$ & $43.4 \pm 9.9$ & 0 & 0 \\
\hline & $\mathrm{L}_{3}$ & 0 & $3.1 \pm 4.9$ & $3.3 \pm 2.9$ & $1.5 \pm 2.2$ & $6.7 \pm 5.9^{*}$ & $62.7 \pm 15.9$ & $18.3 \pm 9.6$ & $115.4 \pm 38.9$ \\
\hline \multirow[t]{3}{*}{28} & $\mathrm{~L}_{1}$ & $13.2 \pm 9.9$ & $57.1 \pm 28.6$ & $0.3 \pm 0.5$ & 0 & 0 & 0 & 0 & 0 \\
\hline & $\mathrm{L}_{2}$ & $0.7 \pm 0.9$ & 0 & $18 \pm 8.8$ & $65.4 \pm 16.6$ & $1.7 \pm 1.7$ & $3.1 \pm 2.4$ & 0 & 0 \\
\hline & $\mathrm{L}_{3}$ & $1.3 \pm 1.9$ & 0 & $1.3 \pm 0.9$ & $7.4 \pm 8.5$ & $17.7 \pm 6.8$ & $34.7 \pm 11.2$ & $46.3 \pm 15.7$ & $33.6 \pm 14.5$ \\
\hline
\end{tabular}

${ }^{\mathrm{a}} \mathrm{t}$ - treatment; ${ }^{\mathrm{b}} \mathrm{c}$ - control; ${ }^{\mathrm{c}}$ - Standard deviation, $*$ - treatment larvae significantly different from control larvae $(\mathrm{P}<0.05)$

Table 6. Effect of solar radiation on free-living stages of cyathostomes $\left(\mathrm{L}_{1}-\right.$ the first stage larvae, $\mathrm{L}_{2}-$ the second stage larvae, $\mathrm{L}_{3}-$ the third stage larvae) contained in water

\begin{tabular}{|c|c|c|c|c|c|c|c|c|}
\hline \multirow{2}{*}{$\begin{array}{c}\text { Time } \\
\text { period of } \\
\text { exposition } \\
\text { (hrs) }\end{array}$} & \multicolumn{2}{|c|}{$\begin{array}{c}\text { Eggs } \\
\text { (able to develop) }\end{array}$} & \multicolumn{2}{|c|}{$\begin{array}{c}\mathrm{L}_{1} \\
\text { (mobile) }\end{array}$} & \multicolumn{2}{|c|}{$\begin{array}{c}\mathrm{L}_{2} \\
\text { (mobile) }\end{array}$} & \multicolumn{2}{|c|}{$\begin{array}{c}\mathrm{L}_{3} \\
\text { (mobile/ damaged) }\end{array}$} \\
\hline & $t^{a}$ & $c^{b}$ & $\mathrm{t}$ & $\mathrm{c}$ & $\mathrm{t}$ & $\mathrm{c}$ & $\mathrm{t}$ & $\mathrm{c}$ \\
\hline 3 & $1.7 \pm 2.4^{\mathrm{c}_{*}}$ & $33.3 \pm 12.1$ & $0 *$ & $98.7 \pm 1.2$ & $0 *$ & $98 \pm 2.2$ & $96 / 13.3 \pm 4.3 / 6.9$ & $100 / 6.3 \pm 0 / 1.5$ \\
\hline 8 & $0 *$ & $64.4 \pm 8.1$ & $0 *$ & $89.4 \pm 5.4$ & $0 *$ & $79.4 \pm 8.9$ & $86.7 / 25.8 \pm 9.0 / 5.8$ & $100 / 9.4 \pm 0 / 4.3$ \\
\hline 16 & $0 *$ & $72.5 \pm 10.9$ & $0 *$ & $70.2 \pm 11.2$ & $0 *$ & $74.5 \pm 8.1$ & $76 / 3 \pm 3.7 / 3.3$ & $97.4 / 5.1 \pm 2.1 / 1.5$ \\
\hline 56 & - & - & 0 & $35.5 \pm 18.6$ & $0 *$ & $51.6 \pm 15.3$ & $48 / 32.2 \pm 16.4 / 8.2$ & $95.1 / 5.2 \pm 3.5 / 3.5$ \\
\hline
\end{tabular}

${ }^{\mathrm{a}} \mathrm{t}$ - treatment; ${ }^{\mathrm{b}} \mathrm{c}$ - control; ${ }^{\mathrm{c}}$ - standard deviation, $*$ - treatment larvae significantly different from control larvae $(\mathrm{P}<0.05)$ 
of cyathostomins showed very small tolerance to UV radiation, most eggs and the preinfective larvae were killed by exposure within $3 \mathrm{hrs}$ and to $1 \mathrm{hr}$, respectively. The survival of infective larvae remained significantly unaffected by UV radiation 56 days $(\mathrm{P}<0.05)$.

The artificial UV radiation has much less destructive effect on the preinfective stage of cyathostomins, influence of Mercury discharge lamp on the infective larvae were conformable when compared with sunshine and artificial UV radiation (Tables $5,7,8$ ).

The majority of infective larvae in desiccated state survived under sun radiation for 1 day, only few $(0.7 \pm 0.9)$ for 4 days. Under artificial UV radiation, infective cyathostomins larvae survived for 3 days only (Table 8). stage are below $23 \%$ RH.

The higher rate of faecal desiccation prevented the larvae from developing to the infective stage before the faeces had reached the critical humidity level. As long as such conditions remained, these larvae never developed to the infective stage and eventually died. Ogbourne (1972) reported resumed development to the infective stage when the faeces were moistened up to 20 days keeping in desiccated state. In our experiment, some preinfective larvae survived the dry conditions up to the time period of 151 days. They were, nevertheless, able to complete the development to the infective stage when the faeces were remoistened not later than after 54 days of desiccation.

Among free-living stages of equine strongyles generally,

Table 7. Effect of artificial UV radiation on free-living stages of equine cyathostomes $\left(\mathrm{L}_{1}-\right.$ the first stage larvae, $\mathrm{L}_{2}-$ the second stage larvae, $\mathrm{L}_{3}-$ the third stage larvae) in water

\begin{tabular}{|c|c|c|c|c|c|c|c|c|}
\hline \multirow{2}{*}{$\begin{array}{c}\text { Time } \\
\text { period of } \\
\text { exposition } \\
\text { (hrs) }\end{array}$} & \multicolumn{2}{|c|}{$\begin{array}{c}\text { Eggs ( } \% \text { able to } \\
\text { develop) }\end{array}$} & \multicolumn{2}{|c|}{$\begin{array}{c}\mathrm{L}_{1} \\
(\% \text { mobile })\end{array}$} & \multicolumn{2}{|c|}{$\begin{array}{c}\mathrm{L}_{2} \\
(\% \text { mobile })\end{array}$} & \multicolumn{2}{|c|}{$\mathrm{L}_{3}(\%$ mobile $/ \%$ damaged $)$} \\
\hline & $\mathrm{t}^{\mathrm{a}}$ & $c^{b}$ & $\mathrm{t}$ & $\mathrm{c}$ & $\mathrm{t}$ & $\mathrm{c}$ & $\mathrm{t}$ & $\mathrm{c}$ \\
\hline 3 & $54.3 \pm 8.38^{\mathrm{c}}$ & $81.1 \pm 19.6$ & $44.3 \pm 18.8$ & $99 \pm 1.4$ & $12 \pm 14.9 *$ & $100 \pm 0$ & $99.3 / 1.7 \pm 0.5 / 1.2$ & $100 / 0 \pm 0$ \\
\hline 8 & $24.7 \pm 18.2$ & $57.4 \pm 21.9$ & 0 & $76.0 \pm 14.4$ & 0 & $76.3 \pm 11.2$ & $69.3 / 3.3 \pm 4.8 * / 0.9$ & $96.77 / 3.3 \pm 3.2 / 2.3$ \\
\hline 16 & $5.3 \pm 5.0 *$ & $89.8 \pm 14.9$ & 0 & $45.7 \pm 13.1$ & 0 & $62.7 \pm 8.1$ & $44 / 19.3 \pm 8.6^{* / 5.4}$ & $89.3 / 5.3 \pm 4.5 / 3.5$ \\
\hline 56 & - & - & 0 & $34.7 \pm 18.8$ & 0 & $21.3 \pm 9.5$ & $28 / 39.3 \pm 9.6 * / 2.1$ & $87 / 9.3 \pm 2 / 2.5$ \\
\hline
\end{tabular}

${ }^{\mathrm{a}} \mathrm{t}$ - treatment; ${ }^{\mathrm{b}} \mathrm{c}$ - control; ${ }^{\mathrm{c}}$ - standard deviation, $*$ - treatment larvae significantly different from control larvae $(\mathrm{P}<0.05)$

Table 8. Effect of natural and artificial UV radiation on desiccated $\mathrm{L}_{3}$ larvae of cyathostomes (\% mobile / \% damaged)

\begin{tabular}{|c|c|c|c|c|}
\hline \multirow{2}{*}{$\begin{array}{c}\text { Time period } \\
\text { of exposition } \\
\text { (days) }\end{array}$} & \multicolumn{2}{|c|}{ Solar radiation } & \multicolumn{2}{|c|}{ Artificial UV radiation } \\
\hline & $t^{a}$ & $c^{b}$ & $\mathrm{t}$ & $\mathrm{c}$ \\
\hline 3 & $4.7^{\mathrm{c}} / 2.6^{\mathrm{d}} \pm 5.2^{*} / 1.1^{\mathrm{e}}$ & $45.5 / 10.2 \pm 9.4 / 5.6$ & $38.7 / 8.4 \pm 27.9 / 6.5$ & $85.4 / 25.1 \pm 15.7 / 9.6$ \\
\hline 4 & $0.7 / 0.2 \pm 0.9 * / 0.1$ & $98 / 5.5 \pm 2.1 / 2.3$ & $0 *$ & $100 / 48.8 \pm 0 / 11.2$ \\
\hline 5 & $0 *$ & $83.4 / 40.5 \pm 14.3 / 21.3$ & $0^{*}$ & $88.2 / 86.6 \pm 5.5 / 0.5$ \\
\hline 10 & $0^{*}$ & $78.4 / 3.9 \pm 10.2 / 2.6$ & $0^{*}$ & $59.1 / 20.6 \pm 14.2 / 5.1$ \\
\hline
\end{tabular}

${ }^{\mathrm{a}} \mathrm{t}$ - treatment; ${ }^{\mathrm{b}} \mathrm{c}$ - control; ${ }^{\mathrm{c}}$ - the number of all revived mobile larvae; ${ }^{\mathrm{d}}$ - the number of revived mobile larvae with visible damage; ${ }^{\mathrm{e}}$ - standard deviation, * - treatment larvae significantly different from control larvae $(\mathrm{P}<0.05)$

\section{Discussion}

Among the strongylid nematodes, the infective larvae are the most resistant stages. Baruš (1963) found live infective larvae on the pasture even after 400 days.

The humidity is of importance for the development of strongyle parasites of horses, the minimum humidity content of faecal pellets as well as temperature being the key factors. As a result of field investigations, Pukhov (1941) suggested that strongyle larvae in horse faeces did not develop to the infective stage when faecal humidity levels dropped below $15-20 \%$. The critical humidity level may be $>14 \%$ - the minimum level at which Mfitilodze and Hutchinson (1987) found completely development, since faecal humidity loss is a gradual process. The findings of the present work confirmed that the faecal humidity limits for the development of cyathostomin eggs to the infective the preinfective stages are susceptible to the effects of environmental factors. It has been noted by many authors that these stages stand desiccation much worse. For example, Shumakovich (1974) and Ogbourne (1972) reported higher sensitivity of the first stage larvae to environmental conditions; Shumakovich (1974) - as pre-viously noted by Bazanova (1948) - writes that the second stage larvae of horse strongyles are quite resistant to de-siccation, while the first stage larvae are rapidly killed. In current study, however, no significant differences were found in the survival in desiccated state in both preinfecti-ve stages of equine cyathostomins.

The ability of infective stages of horse strongyles to survive desiccation has been mentioned in several studies (De Blieck \& Baudet, 1926; Noller \& Schmid, 1930; Pukhov, 1941; Mfitilodze \& Hutchinson, 1987). The ability of horse strongyle infective larvae to resist dry climatic factors is 
well known from laboratory experiments. Infective larvae have been maintained in desiccated state for a long time and afterwards revived (Enigk, 1934; Bazanova, 1948; Ogbourne \& Duncan, 1985). This information is, however, often not expressed explicitly and specified. The survival of the infective larvae in desiccated state in the current study was for 35 days, but some mobile larvae were revived even after 2 months after desiccation. This study has also confirmed that the infective larvae of equine cyathostomins can survive discontinuous desiccation. No differences were found out in the survival of desiccated stages after 108 days. Pastures are of high importance not only for equine nutrition but for the general health of horses. Lethal effects of sun UV radiation on the larvae of gastrointestinal nematodes are considered by many breeders. Especially horse owners tend to believe pastures exposed sun light to lose infectivity rapidly. However, both from this work and from our observations in nature follows that natural UV radiation does not influence the life cycle of infective larvae on pasture to a great extent. First of all the larvae have their own cuticle (sheath of the second stage larva), and, secondly, they live primarily in a shelter against sun rays. According to our results, nevertheless, only the combination of migration to the leaves of grass, subsequent drying out and sunshine can be lethal.

The hard UV radiation is dangerous for living cells and organisms, especially in the hard UV-C region of the spectrum. The ozone layer in the atmosphere is a filter and it is not transparent for electromagnetic waves with shorter wavelengths than $290 \mathrm{~nm}$ (medium UV radiation). The earth surface is then protected from the hard UV radiation. The medium and soft UV radiation is included in the spectrum. The medium UV radiation is harmful for living cells as well and that is the reason why preinfective stages are killed under prolonged solar radiation.

The aim of the present research is to investigate whether UV radiation can actually cut down a potential threat to the cyathostomins and to increase the quality of summer pastures for horses. This is to be done by studying the effects of UV radiation on the most important nematode of horses. We ascertained that UV radiation has lethal effect on preinfective stages of cyathostomins, especially on preinfective larvae. All $\mathrm{L}_{1}$ and $\mathrm{L}_{2}$ larvae were killed on the third hour of direct exposition to sun, eggs after 56 hours. Similarly by equine strongyles, Enigk (1934) considered the preinfec-tive larvae of strongyles much more susceptible to UV ra-diation when compared with infective larvae. By tricho-strongyles of ruminants, Conder (1978) found out that the eggs and preinfective larvae of Haemonchus contortus did not survive 30 hours of exposition to UV lamp, while infective larvae survived for 2 weeks.

Taylor (1938), Ogbourne (1973) and Duncan (1974) mention that infective larvae of horse strongyles live on pastures in summer for $6-8$ weeks. Shagalin (1960) from Turkmenia describes $100 \%$ larvae mortality during summer. English (1979a) writes that infective larvae $\left(\mathrm{L}_{3}\right)$ survive in summer for $2-3$ weeks, and only $0.2 \%$ of infective larvae survive for 6 weeks. Marquardt et al. (1959) show 5 days of survival in Nematodirus spathige. Fernández et al. (2001) reported significant differences between the recovery of Ostertagia ostertagi $\mathrm{L}_{3}$ from plots with short grass and scattered faeces and plots with tall herbage in July. In the present study, a sufficient number of infective larvae in $5 \mathrm{~g}$ of dry faeces were recovered also after 28 days $(\mathrm{P}<$ $0.05) ; 28.0 \pm 9.6 \mathrm{~L}_{3}$ survived $7-8$ hours of direct sunlight exposition.

The survival of infective larvae was only affected by the effects of both desiccation and UV radiation and these stages seemed to be pre-adapted to both forms of environmental conditions when used separately. We observed, however, that the $\mathrm{L}_{3}$ progressively lost its viability as desiccation and UV radiation influenced at the same time. Also Conder (1978) writes about lethal effect of UV radiation on dehydrated infective larvae of $H$. contortus $(3-10 \%$ larvae survived 24 hours), the mortality of $50 \%$ of Trichostrongylus colubriformis after 3 hours of sunlight exposition is described by Taylor (1938). The present work shows survival rate of desiccated infective cyathostomin larvae $4.7 \pm 5.2 \%$ after 3 days of exposition.

During our laboratory experiments, we simulated the solar radiation in the UV region of the spectrum by the special high pressure mercury discharge tube for artificial sunlight generated using special HERAEUS M282 clear quartz glass. Although the artificial UV spectrum and solar spectrum falling on the earth surface in the UV region were comparable, the artificial UV radiation has much less destructive effect on the preinfective stage of cyathostomins. This difference may be caused by faeces shattering on the direct sunlight and it is the reason for lethal direct desiccation.

The study confirmed the tolerance of cyathostomin infective larvae towards both UV radiation and desiccation. UV radiation decreased the number of living larvae, but a considerable number still survived. Hence continuous reinfection of pastures occurs.

The destructive effect of UV radiation for desiccated cyathostome infective larvae has also little epidemiological efficiency, unfortunately, because in nature this situation occurs most often when larvae migrate on grass and they are not able to go back with water film on the ground. With regard to the fact that number of those larvae is low (c. $15 \%$ Hasslinger, 1986) and it requires several days of sunshine for $15 \%$ of larvae to die, it is not possible to expect that owing to sunshine the pastures will be without contamination with infective stages of parasites, especially in the climatic conditions of the Czech Republic.

\section{Acknowledgments}

This work was supported by the research project MSM 6046070901 .

\section{References}

BARUŠ, V. (1962): Helminth fauna of horses in Czechoslovakia. Čs. parasitol, IX: 15 - 94 
BARUŠ, V. (1963): Life cycle of some nematodes from the family Trichonematidae (Witenberg, 1925) in laboratory and field conditions. Čs. parasitol., 10: 23 - 54 (in Czech) BAZANOVA, R. U. (1948): Influence of physical factors on development of eggs and larvae of horse strongyles. Trudy Alma at. Zoovet. Inst., 5: 137 - 142 (in Russian)

BELLO, T. R., GORDON, V. L. (1970): Rapid concentration of strongyle eggs from equine faeces for in vitro studies. Am. J. Vet. Res., 31: $2285-2288$

CONDER, G. A. (1978): The effect of UV radiation on survival of free-living stages of Haemonchus contortus. Proc. Helminthol. Soc. Wash., 45: 230 - 232

ČSN 467092-3., (1999): Assesment of Humidity content. Validity: 1999-01-01. (Czech National Norm n. 467092-3. Validity from January 1, 1999)

De Blieck, L., BAudeT, E. A. R. F, (1926): Contribution a îetude du developpement des strongylidés (sclerostomes) du gros intestin chez le cheval. Ann. Parasitol. Hum. Comp., 4: $87-96$

DUNCAN, J. L. (1974): Field studies on the epidemiology of mixed strongyle infection in the horse. Vet. Rec., 94: 337-345 ECKERT, J. (1960): Die Diagnose des Magen-Darm-Strongyliden-Befalles des Schafes durch Differenzierung der freilebende dritten Larven. Zentralbl. Vet. Med., 7: 612 - 630 ENIGK, K. (1934): Die Widerstandfähigkeit der Entwicklungsstadien der Strongyliden ausserhalb des Wirtstieres. Sch. Arch. Tierheilkd., 67: $363-376$

ENGLish, A.W. (1979a): The epidemiology of equine strongylosis in southern Queensland. 1. The bionomics of the free-living stages in faeces and on pasture. Aust. Vet. J. 55: $299-305$

ENGLiSH, A.W. (1979b): The epidemiology of equine strongylosis in southern Queensland. 2. The survival and migration of infective larvae on herbage. Aust. Vet. J., 55: $306-309$

Fernández, S., SARKUnAS, M., RoEPSTORFF, A. (2001): Survival of infective Ostertagia ostertagi larvae on pasture plots under different simulated grazing conditions. Vet. Parasitol., 96: 291 - 299

HASSLINGER, M. A. (1981): Untersuchungen über den Einfluss verschiedener Temperaturen auf Eier und larven von Pferdstrongyliden unter Laboratoriumsbedingungen sowie das Verhalten dieser exogenen Stadien auf der Weide. Berl. Muench. Tieraerztl. Wochenschr., 94: 1 - 5

HASSLINGER, M. A. (1986): Biologische und Epizootologische Aspecte zu Parasitenbefall und bekämfung beim Pferd. Der Prakt.Tierärzt., 67: 779 - 787

KleI, T. R., Chapman, M. R. (1999): Immunity in equine cyathostome infections. Vet. Parasitol. 85: 123 - 133

Larsson, A., Dimander, S. O., Uggla, A., Waller, P., HogLUND, J. (2006): Effects of single or concurrent infections with Eimeria alabamensis and gastrointestinal nematodes on the performance of calves on pasture. Parasitol. Res., 99: $84-89$

Lichtenfels, J. R., Kharchenko, V. A., KreceK, R. C., GiBBONS, L. M. (1998): An annotated checklist by genus and species of 93 species level names for 51 recognized species of small strongyles (Nematoda : Strongyloidea :
Cyathostominea) of horses, asses and zebras of the world. Vet. Parasitol., 79: 65 - 79

Lichtenfels, J. R., Kharchenko, V. A., KreceK, R. C., GIBBONS, L. M.: Erratum to "An annotated checklist by genus and species of 93 species level names for 51 recognized species of small strongyles (Nematoda: Strongyloidea: Cyathostominea) of horses, asses and zebras of the world". Vet. Parasitol., 84: 137 - 138

Lichtenfels, J. R., Gibbons, L. M., KreceK, R. C. (2002): Recommended terminology and advances in the systematics of the Cyathostominea (Nematoda: Strongyloidea) of horses. Vet. Parasitol., 107: $337-342$

MarquardT, W. C., Fritts, D. H., Senger, C. M., SEGHETTI, L. (1959): The effect of weather on the development and survival of the free-living stages of Nematodirus spathinger (Nematoda: Trichostrongylidae). J. Parasitol., 45: $431-439$

Mfitilodze, M. W., Hutchinson, G. W. (1987): Development of the free-living stages of equine strongyles under laboratory conditions. Vet. Parasitol. 23: $121-133$

Mfitilodze, M. W., Hutchinson, G. W. (1988): Development of the free-living stages of equine strongyles in faeces on pasture in a tropical environment. Vet. Parasitol., 26: $285-296$

Noller, W., Schmid, F.(1930): Über den Einfluss der trockung des Pferdekotes auf die Larvenentwicklung der in ihm enthaltenen Strongylideneiern. Tier. Rund., 36, $543-$ 544

OgBourne, C. P. (1972): Observations on the free-living stages of strongylid nematodes of the horse. Parasitology 64: $461-477$

OgBourne, C. P. (1973): Survival on herbage plots of infective larvae of strongylid nematodes of the horse. $J$. Helminthol., 48, 9 - 16

OGBourne, C. P., Duncan, J. L. (1985): Strongylus vulgaris in the horse: its biology and veterinary importance. 2. Commonwealth Institute of Parasitology, Comm. Agric. Bureaux. Farnham Royal Slough, SL2 3BN United Kingdom, $1-65$

PuKHOV, V. I. (1941): Control of Strongyle Infection in herd of horses. Trudy XV Plenarni Vet. Sect. Akad. Selskochozaistvennych Nauk, Moskva: 173 - 180 (in Russian) Rommel, M., EcKert, J., Kutzer, E., Körtling, W., SCHNIEDER, T. (2000): Veterinärmedizinische Parasitologie. 5., vollständig neubearbeitete Auflage. Parey Buchverlag, Berlin, pp 915

Rupasinghe, D., OGBouRne, C. P. (1978): Laboratory studies on the effect of temperature on the development of the free-living stages of some strongylid nematodes of the horse. Z. Parasitenkd., 55: 249 - 253

SAS (computer program) (2004). Cary, NC: SAS Institute Inc.

Shagalin, S. F. (1960): Development of the larvae of pathogenic nematodes of the horse in the Turkmenistan environment. Tr. Inst. Zool. Parazitol. Akad. Nauk. Turkm. SSR 5: $237-242$ (in Russian)

SHUMAKOVICH, E. E. (1974): K izucheniyu bioekologii lichinok strongilat loshadei. (Studies on the ecology of 
horse strongyle larvae.) In ERSHOV V.S. et al. (Eds): Gelminty cheloveka zhivototnykh i rastenii. Moscow, Izd. Nauka: 368 - 374 (in Russian)

STROMBERG, B. E. (1997): Environmental factors influencing transmission. Vet. Parasitol., 72: $247-256$

TAYLOR, E. L. (1938): Observations on the bionomics of Strongyloid larvae in pastures. I. The duration of infection in pasture herbage. Vet. Rec., 40: $1265-1272$

RECEIVED DECEMBER 7, 2006
WetzeL, R. (1930): Some observations on the development of eggs and free-living larvae of Strongylus equinus. J. Parasitol., 17: 53

Wetzel, R. (1931): Some observations on the development of eggs and larvae of Strongylus vulgaris. J. Parasitol., $17: 55-57$

Wetzel, R. (1951): Verbesserte McMaster - Kammer zum Auszählen von Wurmeiern. Tiearar. Umsch, 6, 209-210

ACCEPTED DECEMBER 20, 2007 